\title{
Surfactant Enhanced Chemofiltration of Zinc Traces Previous to Their Determination by Solid Surphase Fluorescence
}

\author{
Mabel Vega ${ }^{1}$, Miriam Augusto ${ }^{1}$, María C. Talío ${ }^{2}$, Liliana P. Fernández ${ }^{2 *}$ \\ ${ }^{1}$ Instituto de Ciencias Básicas, FFHA, Universidad Nacional de San Juan, \\ San Juan, Argentina \\ ${ }^{2}$ Área de Química Analitica, Facultad de Química, Bioquímica y Farmacia, Universidad Nacional \\ de San Luis, Instituto de Química de San Luis \\ (INQUISAL-CONICET), Chacabuco y Pedernera, San Luis, Argentina \\ E-mail:"lfernand@unsl.edu.ar \\ Received October 19, 2011; revised November 27, 2011; accepted December 8, 2011
}

\begin{abstract}
Surfactant enhanced chemofiltration on Nylon membranes pre-treated with hexadecyltrimethylammonium bromide (HTAB) and eosin dye (eo) is proposed for zinc traces quantification by solid surphase spectrofluorimetry $\left(\mathrm{SSF}, \lambda_{\mathrm{exc}}=532 \mathrm{~nm} ; \lambda_{\mathrm{em}}=548 \mathrm{~nm}\right.$ ). Operational variables which have influence on quantitative retention of metal complex have been studied and optimized. At optimal experimental conditions, quantitative recovery was reached with a detection limit of $0.662 \mathrm{pg} \cdot \mathrm{L}^{-1}$ and quantification limit of $2.20 \mathrm{pg} \cdot \mathrm{L}^{-1}$. The calibration sensitivity was of $1.22 \mathrm{~L} \cdot \mathrm{pg}^{-1}$ for the new methodology with a linear range of $2.20 \mathrm{pg} \cdot \mathrm{L}^{-1}$ to 779 $\mathrm{pg} \cdot \mathrm{L}^{-1} \mathrm{Zn}$ (II). The tolerance levels of potential interfering ions were studied with good results. Recuperation studies were carried out by standard addition method applied to natural water samples (San Juan, Argentine) without previous treatment. The reproducibility (between-days precision) was also evaluated over 3 days by performing five determinations each day. $\mathrm{CV} \%$ was 0.37 . The performing obtained in sensitivity and selectivity thanks to chemofiltration step, converts the proposed methodology in an adequate alternative to conventional techniques for $\mathrm{Zn}$ (II) traces determination.
\end{abstract}

Keywords: Zinc Traces, Eosin Dye, Surfactant Enhanced Chemofiltration, Solid Surphase Fluorescence, Natural Water Samples

\section{Introduction}

Water sources contamination is a frequent form of environmental pollution. Despite of great advances in modern analytical instrumentation, preconcentration procedures are still often required for the precise and accurate determination of trace metals in natural waters. Many techniques, e.g. solvent, cloud point and solid-phase extractions, volatilization, electrodeposition, ion-exchange and coprecipitation, have been combined with instrumental analytical methods so far [1-4].

Solid phase extraction (SPE) is a rapid, simple, economical preconcentration step, environmentally-friendler than the traditional liquid-liquid extraction. SPE followed by electrothermal atomic absorption spectrometry (ET-AAS), inductively coupled plasma atomic emission
(ICP-AES) or ICP-mass spectrometry are suitable for analysis of metal traces $[5,6]$.

Nowadays, investigators are interested in improving the selective preconcentration of the sorbents used in SPE. This objective is particularly important when analyzing complex matrices. Several solid materials as filter papers, silica gel, exchange resins, aluminium oxide, poly(vinylalcohol), $\mathrm{C}_{18}$ membranes, cyclodextrines, between others have been successfully employed as supports for SPE. Recently, Nylon has proved to be an adequate support for luminescent detection of organic compounds [7-9]. Experimental results shown that this support possesses good selectivity, low background signal and can be used without previous treatment.

Zinc is an essential trace element of great importance in living beings. It plays an important role in several bio- 
chemical processes [10], however, if it is in excess, this metal can also produce damage in the human body, including nausea, vomiting, fever, arrhythmias/dysrhythmias and increase susceptibility to autoimmune reactions, between others [11].

Spectrophotometry $[12,13]$, atomic absorption spectrometry $[14,15]$, neutron activation analysis [16], inductively coupled plasma-atomic emission spectroscopy $[17,18]$, and inductively coupled plasma-mass spectrometry $[19,20]$ are widely applied to the determination for zinc at trace levels.

The use of micellar media has been investigated in order to improve analytical parameters of instrumental methodologies such as sensitivity and selectivity [21-25]. Particularly, micellar enhanced separation method have been extensively studied for removal of heavy metals and organic pollutants by using ultrafiltration membranes [26-28]. Additionally, the feasibility of realizing chemical separation processes without polluting solvents has turned to surfactant organized media in a very attractive strategy.

In this work, chemisorption of zinc on nylon membranes previously treated with diluted solution of cationic surfactant HTAB and eo dye is proposed for subsequent quantification by SSF in natural water samples. The study was carried out analyzing the different factors which influence on the chemisorption processes and fluorescence intensity of the Zn (II)-HTAB-eo association. Additionally, the stability of samples was also explored during a period of one month.

\section{Experimental}

\subsection{Reagents}

$1 \times 10^{-9} \mathrm{~mol} \cdot \mathrm{L}^{-1} \mathrm{Zn}$ (II) stock solutions were prepared by dilution of $100 \mathrm{~g} \cdot \mathrm{mL}^{-1}$ standard solution plasma-pure (Leeman Labs, Inc.)

$1 \times 10^{-7} \mathrm{~mol} \cdot \mathrm{L}^{-1}$ eosin (sodium bromofluorescein, $\mathrm{C}_{20} \mathrm{H}_{6} \mathrm{O}_{5} \mathrm{Br}_{4} \mathrm{Na}_{2}$, H.E-Daniel Ltd., England) stock solution was weekly prepared by dissolution of the appropriate amount in ultrapure water.

A $1 \times 10^{-2} \mathrm{~mol} \cdot \mathrm{L}^{-1} \mathrm{HTAB}$ purchased from Tokyo Kasei Industries (Chuo-Ku, Tokyo, Japan) was prepared by dissolution of the appropriate amount in ultrapure water.

A $1 \times 10^{-2} \mathrm{~mol} \cdot \mathrm{L}^{-1}$ sodium tetraborate (Mallinckrodt ChemicalWorks, New York, Los Angeles, St. Louis, USA) solution was prepared, obtaining the desired $\mathrm{pH}$ by addition of dilute $\mathrm{HClO} 4$ (Merck) or $\mathrm{NaOH}$ (Mallinckrodt Chemical Works) solutions.

Nylon membranes (Millipore, Sao Paulo, Brazil) 0.45 $\mu \mathrm{m}$ pore size and $47 \mathrm{~mm}$ diameter were used in chemisorption studies.
All used reagent were analytical quality.

\subsection{Apparatus}

Fluorescence measurements were done using a Shimadzu RF-5301 PC spectrofluorometer equipped with a $150 \mathrm{~W}$ Xenon lamp and solid sample holder with GF-UV35 filter. Instrument excitation and emission slits were both adjusted to $1.5 \mathrm{~nm}$.

A combined glass electrode and a pHmeter (Orion Expandable Ion Analyzer, Orion Research, Cambridge, MA, USA) Model EA 940 were used for pH adjustments.

A centrifuge was used in water sample processing.

A Gilson Minipuls 3 peristaltic pump with PVC pumping tubes coupled to an in-line filter holder $47 \mathrm{~mm}$ (Millipore) was use for filtrating sample/standard solutions.

All used glass materials were previously washed with a $10 \% \mathrm{v} / \mathrm{v} \mathrm{HNO}_{3}$ water solution and then with ultrapure water.

\subsection{General Procedure}

Nylon membranes were impregnated in batch by contact with $100 \mu \mathrm{L}$ HTAB $1 \times 10^{-2} \mathrm{~mol} \cdot \mathrm{L}^{-1}$ and then in $5 \mathrm{~mL}$ of $1 \times 10^{-7} \mathrm{~mol} \cdot \mathrm{L}^{-1}$ eo solution during $5 \mathrm{~min}$. Membranes were dried at room temperature and reserved in dried ambient $\left(20^{\circ} \mathrm{C}-25^{\circ} \mathrm{C}\right)$ up to filtration step. Later, a dried membrane was put in filtration holder.

Adequate volume of sample/standard Zn (II) solution $\left(2.20 \mathrm{pg} \cdot \mathrm{L}^{-1}-779 \mathrm{pg} \cdot \mathrm{L}^{-1}\right), 100 \mu \mathrm{L}$ buffer borax solution 1 $10^{-2} \mathrm{~mol} \cdot \mathrm{L}^{-1}(\mathrm{pH}=9.22)$, were placed in a $10 \mathrm{~mL}$ graduated centrifuge tube. The whole mixture was diluted to $10 \mathrm{~mL}$ with ultrapure water. Systems were filtrated across eo-HTAB-impregned membranes, using peristaltic pump at $0.1 \mathrm{~mL} \cdot \mathrm{min}^{-1}$ and dried at room temperature.

Zinc was determined on the membranes by SSF at $\lambda_{\mathrm{em}}$ $=548 \mathrm{~nm}$ and $\lambda_{\mathrm{exc}}=532 \mathrm{~nm}$, using a solid sample holder (Figure 1).

\subsection{Interferences Study}

Different amounts of ions $(1 / 1,1 / 10,1 / 100$ and $1 / 1000$ $\mathrm{Zn}$ (II)/interferent ratio) were added to the test solution containing $0.49 \mathrm{ng} \cdot \mathrm{L}^{-1} \mathrm{Zn}$ (II) and general procedure was applied.

\subsection{Accuracy Study}

$250 \mu \mathrm{L}$ of water samples were spiked with increasing amounts of $\mathrm{Zn}$ (II) $\left(0.33-0.65 . \mathrm{ng} \cdot \mathrm{L}^{-1}\right)$. Zinc contents were determined by proposed methodology. 
Step 1

5 minutes

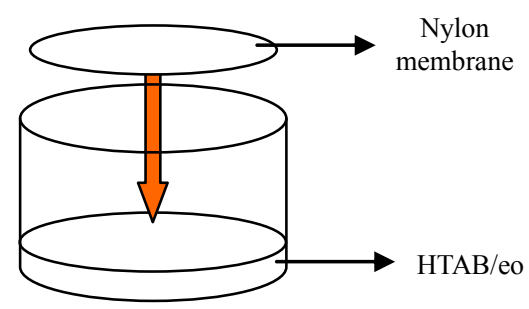

Step 2

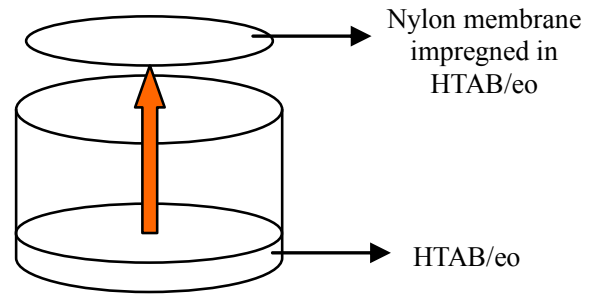

Step 3

Membrane dried at room temperature

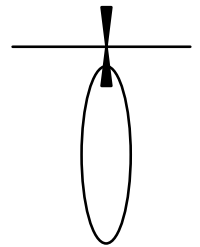

Step 5

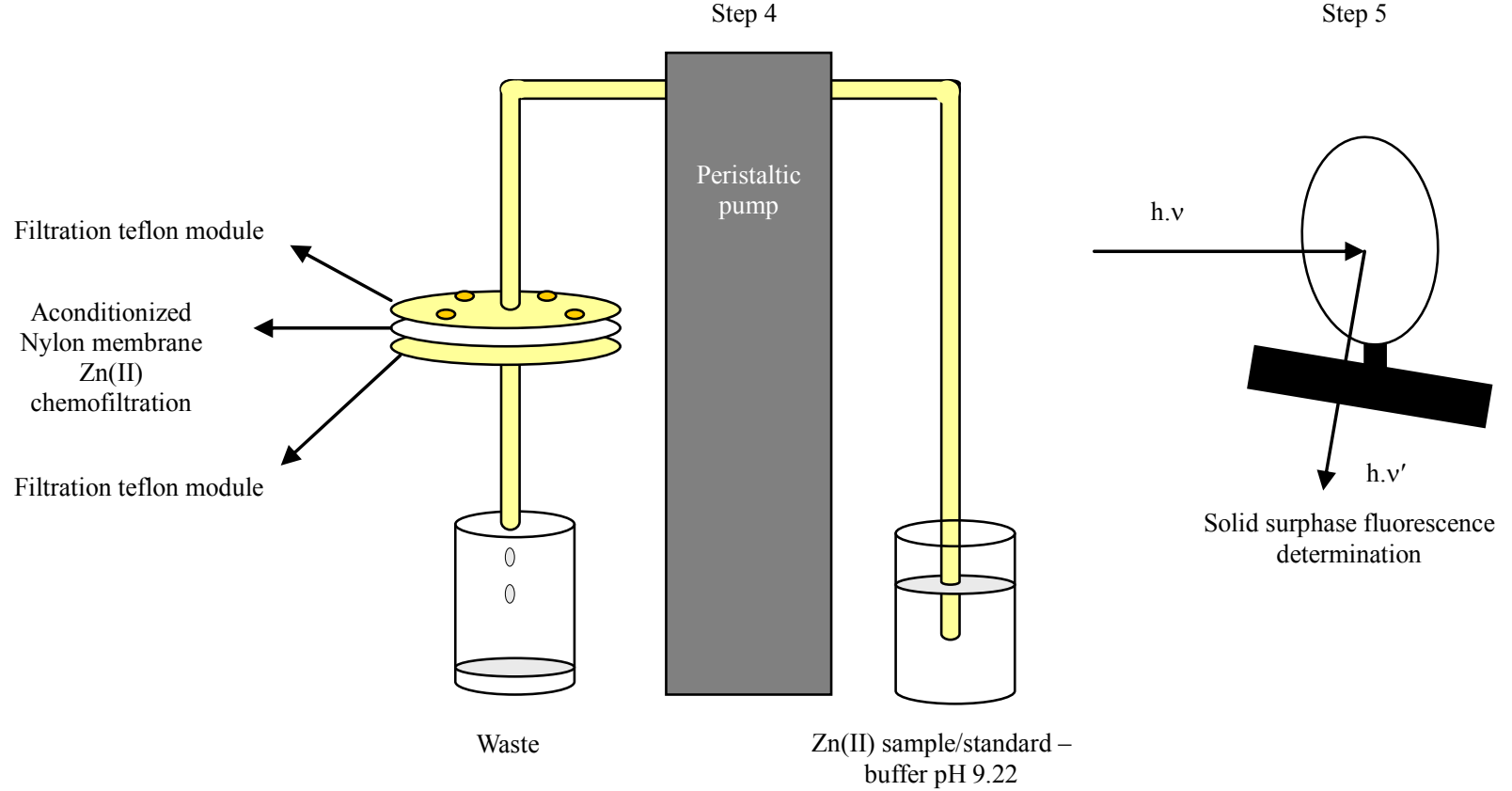

Figure 1. Schematic representation of general procedure of proposed methodology.

\subsection{Precision Study}

The repeatability (within-day precision) of the method was tested for replicate water samples $(n=3)$ spiked with 0.49 . $\mathrm{ng} \cdot \mathrm{L}^{-1} \mathrm{Zn}$ (II); metal contents were determined by proposed methodology.

\subsection{Recovery Procedure}

$250 \mu \mathrm{L}$ water was spiked with increasing amounts of $\mathrm{Zn}$ (II) $\left(0.33-0.65 \mathrm{ng} \cdot \mathrm{L}^{-1}\right)$ at three levels and treated, following proposed methodology.

\subsection{Stability Test of Water Samples}

$250 \mu \mathrm{L}$ of water samples were spiked with increasing amounts of Zn (II) $0.33-0.65 \mathrm{ng} \mathrm{L}^{-1}$ ). Zn (II) contents were determined by proposed methodology at different times ( 1 day, 1 week, 2 weeks, 1 month after sampling) using preservation in refrigerator at $4^{\circ} \mathrm{C}$.

\section{Results and discussion}

\subsection{Study of Zn (II)-Eo System: Support and Surfactant Selection}

Eosin yellowish [2', 4', 5', 7'-tetrabromo-3', 6'-di-hydroxyspiro[isobenzofuran-1(3H),9'-[9H]xanthen]-3-one] is a xanthene group dye with strong absorption in the visible region of electromagnetic spectrum. Previous studies have shown that this dye presents the feasibility of forming association with metallic ions $[25,29,30]$.

In preliminary assays, aqueous systems containing eo and $\mathrm{Zn}$ (II) were prepared adjusting a $\mathrm{pH}$ from 6.0 to 10.0. Fluorescent signals were checked without alteration of fluorescent emission of eo for presence of $\mathrm{Zn}$ (II). As a consequence, SPE was explored for eo-Zn (II) system; Nylon membrane as solid support was put in contact with 
eo solution in order to assuring the retention of this dye. In this step, it didn't observe variation on eo fluorescent signal for the presence of $\mathrm{Zn}$ (II).

Surfactants have been used in enhancing membrane filtration for the removal of metal ions in aqueous solutions due to their high selectivity properties [26,27]. Taking into account previous reports, the support impregnation was carried out with different surfactants and eo dye. Then, $\mathrm{Zn}$ (II) solution was filtrated across the pre-treated support. In presence of $\mathrm{Zn}$ (II), an enhancement of fluorescent emission of eo was observed for systems with the cationic HTAB surfactant (Figure 2). Enhanced separation by surfactant can be explained for the adsorption of metallic ions on the polar head of the surfactants surface.

Several solid supports were assayed for SPE: cellulose acetate, Nylon and esters mixture. Among examined supports, Nylon membranes showed to be the most adequate for the quantitative metal retention. Likewise, Nylon membranes are usable without purification, are commercially available and it poses low cost

The use of Nylon membranes resulted satisfactory to performing of fluorescent eo signal with low background. Additionally, the pre-treated solid support with HTABeo mix allowed $\mathrm{Zn}$ (II) retention put in evidence by the increased fluorescent response. Quantitative metal retention was verified by double filtration on a new pretreated membrane and later fluorescent detection with a signal similar to eo dye (blank).

Therefore, Nylon membrane support was selected to following experiences.

\subsection{Effect of Eosin and HTAB Concentration}

To ensure quantitative Zn (II) retention on Nylon support, tests were carried out by varying the concentration of eo from $1 \times 10^{-8}$ to $5 \times 10^{-7} \mathrm{~mol} \cdot \mathrm{L}^{-1}$. A concentration of $110^{-7}$

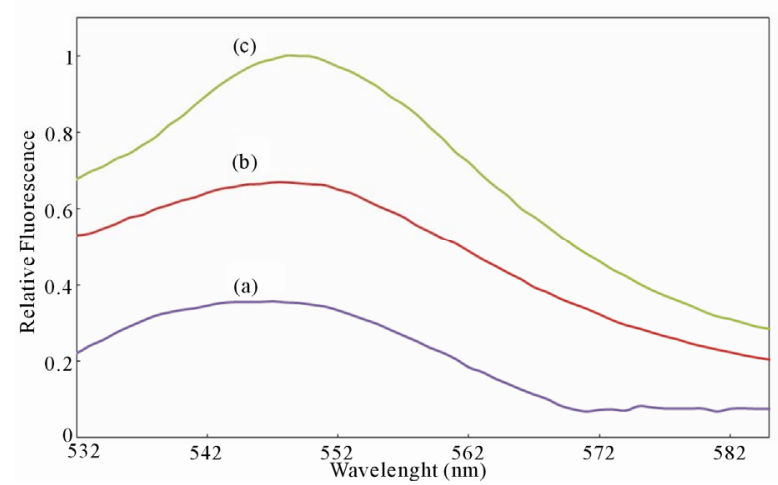

Figure 2. Fluorescent spectra (SSF) of Zn (II)-HTAB-eo system. (a): Membrane of nylon treated with HTAB and eo $1 \times 10^{-7} \mathrm{~mol}^{-1}$; (b): Idem A with $\mathrm{Zn}$ (II) $0.33 \mathrm{ng} \cdot \mathrm{L}^{-1}$; (c): Idem A with $\mathrm{Zn}(\mathrm{II}) 0.49 \mathrm{ng} \cdot \mathrm{L}^{-1}$. $\mathrm{mol} \cdot \mathrm{L}^{-1}$ was selected as optimal because it resulted enough to warrant an adequate eo excess respect to expected $\mathrm{Zn}$ (II) contents in natural water samples.

HTAB concentration was too optimized. With this propose, systems were preparing varying HTAB concentration from 0 to $1 \times 10^{-3} \mathrm{~mol} \cdot \mathrm{L}^{-1}$, maintaining constant eo concentration at $1 \times 10^{-7} \mathrm{~mol} \cdot \mathrm{L}^{-1}$. The best improvement in fluorescent signal was achieve at HTAB concentration of $2 \times 10^{-4} \mathrm{~mol} \cdot \mathrm{L}^{-1}$ (Figure 3 ). At this concentration level, monolayer on solid support are formed for surfactant monomers characterized by extensive surface area, facilitate $\mathrm{Zn}$ (II) retention.

This concentration was selected for following studies.

\subsection{Membrane/HTAB-eo Contact Time}

Nylon membranes were submerged in $2 \times 10^{-4} \mathrm{~mol} \cdot \mathrm{L}^{-1}$ $\mathrm{HTAB}$ and $1 \times 10^{-7} \mathrm{~mol} \cdot \mathrm{L}^{-1}$ eo solution during different time. Quantitative eo retention was reached in five minutes of contact time checked by SSF eo signal. Following assays were realized using Nylon membranes pre-treated during five minutes.

\subsection{Influence of Filtration Flow Rate}

With the purpose of optimize the sampling rate, the filtration speed was varied between 0.05 and 0.25 $\mathrm{mL} \cdot \mathrm{min}^{-1}$, maintaining constant other experimental conditions. A filtration flow rate of $0.1 \mathrm{~mL} \cdot \mathrm{min}^{-1}$, was the most adequate for the quantitative $\mathrm{Zn}$ (II) retention.

\section{5. pH of Retention. Buffer Concentration}

$\mathrm{pH}$ is an experimental variable of weight when exists an association equilibrium as in the eo- $\mathrm{Zn}$ (II) system. In order to obtain the optimal retention of metal and the maximum SSF signal, aqueous systems containing con-

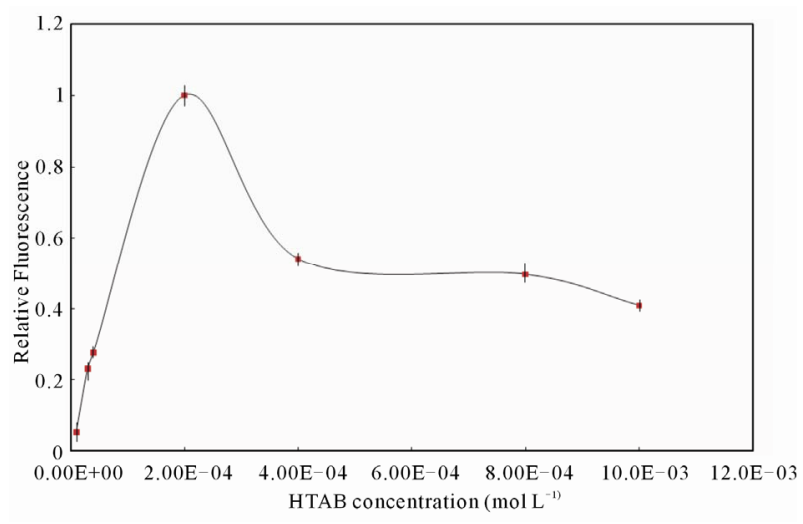

Figure 3. Influence of HTAB concentration on Zn (II) retention. $\mathrm{Zn}$ (II) $0.49 \mathrm{ng} \cdot \mathrm{L}^{-1}$ on Nylon membrane treated with eo $1 \times 10^{-7} \mathrm{~mol} \cdot \mathrm{L}^{-1}$. 
stant concentration of $\mathrm{Zn}$ (II) were prepared, adjusting their $\mathrm{pH}$ values between 7.0 and 10.5 by addition of buffer solution sodium tetraborate. Then, solutions were filtrated across the pre-treated support and SSF signals were determined.

The obtained results showed a maximum level of retention of $\mathrm{Zn}(\mathrm{II})$-eo association for $\mathrm{pH}$ values of 8.7 to 9.5 (Figure 4). For following experiences, a $\mathrm{pH}$ value of 9.2 was chosen.

Then, the buffer concentration was tested in order to obtain the maximum fluorescent signal. The concentration of sodium tetraborate buffer was varied from $5 \times$ $10^{-3}$ to $0.01 \mathrm{~mol} \cdot \mathrm{L}^{-1}$. Buffer concentration of $5 \times 10^{-2}$ $\mathrm{mol} \cdot \mathrm{L}^{-1}$ was chosen as optimal.

Table 1 summarizes studied experimental parameters and their optimal values. At optimal experimental conditions, Zn (II) quantitative retention was verified by a second filtration procedure through a new pre-treated membrane; the obtained fluorescence signal was similar to eo signal (blank).

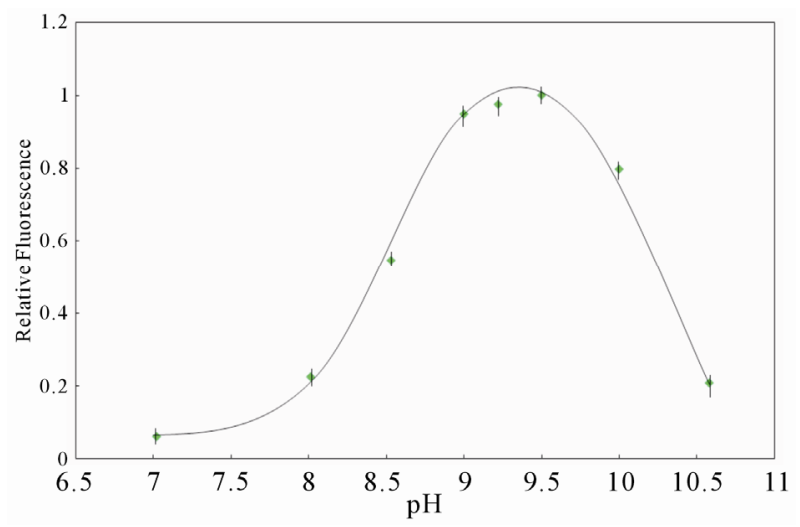

Figure 4. Influence of pH on $\mathrm{Zn}$ (II) retention. $\mathrm{Zn}$ (II) 0.49 $\mathrm{ng} \cdot \mathrm{L}^{-1}$ on Nylon membrane treated with $2 \times 10^{-4} \mathrm{~mol} \cdot \mathrm{L}^{-1}$ HTAB and eo $1 \times 10^{-7} \mathrm{~mol} \cdot \mathrm{L}^{-1}$.

Table 1. Studied optimal experimental conditions and analytical parameters for Zn (II) determination by SSF.

\begin{tabular}{lcc}
\hline \multicolumn{1}{c}{ Parameters } & Studied range & $\begin{array}{c}\text { Optimal condi- } \\
\text { tions }\end{array}$ \\
\hline $\mathrm{pH}$ & $7.0-10.5$ & 9.20 \\
$\begin{array}{l}\text { Buffer sodium } \\
\text { tetraborate }\end{array}$ & $5 \times 10^{-3}-0.01 \mathrm{~mol} \cdot \mathrm{L}^{-1}$ & $5 \times 10^{-2} \mathrm{~mol} \cdot \mathrm{L}^{-1}$ \\
Eo concentration & $1 \times 10^{-8}-5 \times 10^{-7}$ & $1 \times 10^{-7} \mathrm{~mol} \cdot \mathrm{L}^{-1}$ \\
HTAB concentration & $0-1 \times 10^{-3} \mathrm{~mol} \cdot \mathrm{L}^{-1}$ & $2 \times 10^{-4} \mathrm{~mol} \cdot \mathrm{L}^{-1}$ \\
Contact time & $0-700 \mathrm{~min}$ & $5 \mathrm{~min}$ \\
LOD & - & $0.66 \mathrm{pg} \cdot \mathrm{L}^{-1}$ \\
LOQ & - & $2.20 \mathrm{ng} \cdot \mathrm{L}^{-1}$ \\
LOL & - & $2.20-779 \mathrm{pg} \cdot \mathrm{L}^{-1}$ \\
Calibration sensitivity & - & $1.22 \mathrm{~L} \cdot \mathrm{pg}^{-1}$ \\
\hline
\end{tabular}

\section{Applications}

\section{Stability Studies of Water Samples}

Natural water samples belonging to San Juan (Argentine) were spiked with increasing amounts of $\mathrm{Zn}$ (II) and then processed at different times by proposed methodology. Samples were maintained in refrigerator at $4^{\circ} \mathrm{C}$. The results are presented in Table 2; it can be inferred that water samples show optimal stability for Zn (II) determination by developed methodology, during the studied period of one month.

\section{Tolerance Studies}

In order to study the effects of representative potential interfering species on Zn (II) determination using developed methodology, assays were carried out at the concentration levels at which they may occur in the natural water samples. An ion was considered interfering, when it caused a variation in the fluorescent signal of the sample greater than $\pm 5 \%$. Figure 5 shows the obtained re-

Table 2. Stability test of water samples.

\begin{tabular}{ccc}
\hline Time (h) & $\mathbf{Z n}(\mathbf{I I})\left(\mathbf{n g} \cdot \mathbf{L}^{-\mathbf{1}}\right)$ & $\mathbf{C V}$ \\
\hline 0 & 1.10 & 0.37 \\
24 & 1.12 & 0.21 \\
168 (seven days) & 1.14 & 0.26 \\
360 (fifteen days) & 1.14 & 0.22 \\
720 (thirty days) & 1.12 & 0.32 \\
\hline
\end{tabular}

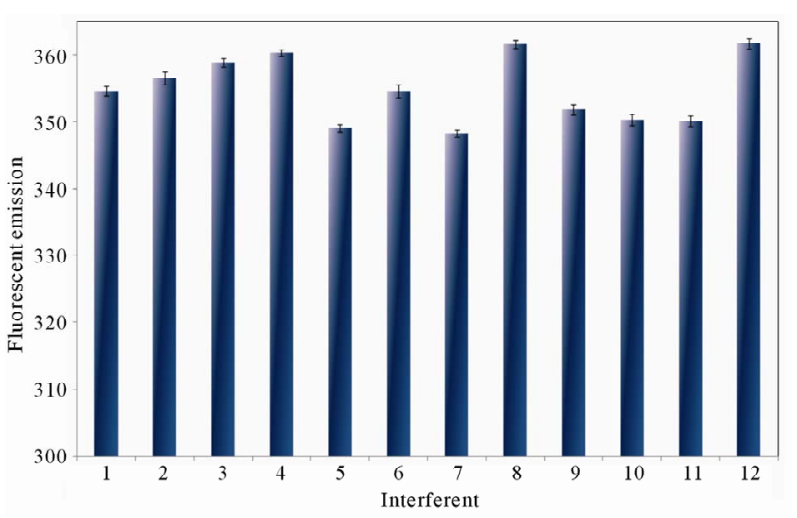

Figure 5. Tolerances of cations for developed methodology for $1 / 1000 \mathrm{Zn}$ (II)/interferent ratio. 1 : $\mathrm{Zn}$ (II) $0.49 \mathrm{ng} \cdot \mathrm{L}^{-1}$; 2 : $\mathrm{Zn}$ (II) in presence of $\mathrm{K}$ (I); 3: Zn (II) in presence of $\mathrm{Na}$ (I); 4: $\mathrm{Zn}$ (II) in presence of $\mathrm{Ni}$ (II); $5: \mathrm{Zn}$ (II) in presence of $\mathrm{Fe}$ (III); 6: Zn (II) in presence of Ca (II); 7: Zn (II) in presence of Mn (II); 8: Zn (II) in presence of Ba (II); 9: Zn (II) in presence of $\mathrm{Sr}$ (II); 10: $\mathrm{Zn}$ (II) in presence of $\mathrm{Pb}$ (II); 11: $\mathrm{Zn}$ (II) in presence of Cd (II); 12: Zn (II) in presence of Mg (II). 
sults for assayed cations. Obtained results put in evience the usefulness and robustness of the new methodology for the quantification of $\mathrm{Zn}$ (II) traces in presence of different ions at 1/1000 $\mathrm{Zn}$ (II)/interferent ratio.

\section{Analytical Performance}

Standard addition method was applied in order to evaluating the accuracy of the methodology. The reproducibility of the method was estimated repeating the proposed approach, 3 times for each sample. Recoveries of $\mathrm{Zn}$ (II) in eight natural water samples based on the average of replicate measurements are illustrated in Table 3.

For determine the repeatability (within-day precision) of the method, replicate water samples $(n=5)$ were analyzed by proposed methodology. The precision was better than $0.15 \mathrm{CV} \%$ for zinc contents. The reproducibility (between-days precision) was also evaluated over 3 days by performing six determinations each day. CV\% was 0.37 .

\section{Conclusions}

Zinc traces determination has been realized by SSF using separation/preconcentration step on Nylon membranes containing cationic surfactant HTAB at sub-micellar concentration and eo dye. Enhanced separation and se-

Table 3. Recovery study. Zn (II) determination in natural water of San Juan (Argentine).

\begin{tabular}{|c|c|c|c|}
\hline Sample & $\begin{array}{l}\mathrm{Zn}(\mathrm{II}) \text { added } \\
\left(\mathrm{ng} \cdot \mathrm{L}^{-1}\right)\end{array}$ & $\begin{array}{l}\mathrm{Zn} \text { (II) found } \pm \mathrm{SD} \\
\left(\mathrm{ng} \cdot \mathrm{L}^{-1}\right)\end{array}$ & $\begin{array}{l}\text { Recovery } \\
(\%, \mathrm{n}=3)\end{array}$ \\
\hline \multirow{3}{*}{1} & - & $1.10 \pm 0.37$ & - \\
\hline & 0.33 & $1.42 \pm 0.21$ & 99.09 \\
\hline & 0.49 & $1.57 \pm 0.14$ & 98.12 \\
\hline \multirow{3}{*}{2} & - & $1.46 \pm 0.11$ & - \\
\hline & 0.33 & $1.80 \pm 0.18$ & 100.68 \\
\hline & 0.49 & $1.93 \pm 0.12$ & 98.63 \\
\hline \multirow{3}{*}{3} & - & $0.98 \pm 0.06$ & - \\
\hline & 0.33 & $1.31 \pm 0.05$ & 100.40 \\
\hline & 0.49 & $1.46 \pm 0.15$ & 99.62 \\
\hline \multirow{3}{*}{4} & - & $1.08 \pm 0.16$ & - \\
\hline & 0.33 & $1.37 \pm 0.06$ & 96.30 \\
\hline & 0.49 & $1.57 \pm 0.08$ & 100.00 \\
\hline \multirow{3}{*}{5} & - & $1.00 \pm 0.03$ & - \\
\hline & 0.33 & $1.36 \pm 0.14$ & 103.00 \\
\hline & 0.49 & $1.54 \pm 0.03$ & 105.00 \\
\hline \multirow{3}{*}{6} & - & $1.02 \pm 0.14$ & 10000 \\
\hline & 0.33 & $1.35 \pm 0.19$ & 100.00 \\
\hline & 0.49 & $1.52 \pm 0.03$ & 101.00 \\
\hline \multirow{3}{*}{7} & - & $1.09 \pm 0.13$ & - \\
\hline & 0.33 & $1.47 \pm 0.03$ & 104.60 \\
\hline & 0.49 & $1.57 \pm 0.08$ & 99.08 \\
\hline \multirow{3}{*}{8} & - & $0.41 \pm 0.12$ & - \\
\hline & 0.33 & $0.73 \pm 0.04$ & 97.60 \\
\hline & 0.49 & $0.92 \pm 0.03$ & 104.90 \\
\hline
\end{tabular}

lectivity can be explained for the adsorption of metallicions on the polar head of the surfactants surface. The reached sensitivity was comparable at those arrived with atomic spectroscopies. The good tolerance at elevated levels of regular foreign constituents put in evidence the high selectivity and versatility of the new methodology. Stability of natural water samples during a month was studied with good results. Precision and accuracy were tested with good results. The proposed methodology represents a contribution to zinc environmental monitoring and a suitable alternative to routine metal analysis methods, with advantages referred to simplicity, low cost and adequate sampling rate, using a simple and inexpensive instrumental. The developed methodology was successfully applied to $\mathrm{Zn}$ (II) quantification to natural water samples belonging of different sites of sampling of San Juan (Argentine).

\section{Acknowledgements}

The authors wish to thanks to Instituto de Química San Luis-Consejo Nacional de Investigaciones Científicas y Tecnológicas (INQUISAL-CONICET) and National University of San Luis (Project 22/Q828) for the financial support.

\section{References}

[1] A. Mizuike, "Enrichment Techniques for Inorganic Trace Analysis," Springer Verlag, Berlin, 1983.

[2] Y. A. Zolotov and N. M. Kuz'min, "Preconcentration of Trace Elements," In: G. Svehla, Ed., Comprehensive Analytical Chemistry, Elsevier, Amsterdam, 1990.

[3] Z. B. Alfassi and C. M. Wai, "Preconcentration Techniques for Trace Elements," CRC Press, Boca Ratón, 1992.

[4] L. R. Dutra, H. F. Maltez and E. Carasek, "Development of an on-Line Preconcentration System for Zinc Determination in Biological Samples," Talanta, Vol. 69, No. 2, 2006, pp. 488-493. doi:10.1016/j.talanta.2005.10.019

[5] M. Karbasia, B. Jahanparast, M. Shamsipur and J. Hassan, "Simultaneous Trace Multielement Determination by ICP-OES after Solid Phase Extraction with Modified Octadecyl Silica Gel," Journal of Hazardous Materials, Vol. 170, No. 1, 2009, pp. 151-155. doi:10.1016/j.jhazmat.2009.04.119

[6] J. Suleiman, B. Hu, C. Huang and N. Zhang, "Determination of $\mathrm{Cd}, \mathrm{Co}, \mathrm{Ni}$ and $\mathrm{Pb}$ in Biological Samples by Microcolumn Packed with Black Stone (Pierre Noire) Online Coupled with ICP-OES," Journal of Hazardous Materials, Vol. 157, No. 2-3, 2008, pp. 410-417. doi:10.1016/j.jhazmat.2008.01.014

[7] R. A. Correa and G. M. Escandar, "A New Analytical Application of Nylon-Induced Room-Temperature Phosphorescence: Determination of Thiabendazole in Water 
Samples," Analytica Chimica Acta, Vol. 571, No. 1, 2006, pp. 8-65.doi:10.1016/j.aca.2006.04.052

[8] G. M. Escandar, D. González Gómez, A. Espinosa Mansilla, A. Muñoz de la Peña and H. C. Goicoechea, "Determination of Carbamazepine in Serum and Pharmaceutical Preparations Using Immobilization on a Nylon Support and Fluorescence Detection," Analytica Chimica Acta, Vol. 506, No. 2, 2004, pp. 161-170. doi:10.1016/j.aca.2003.11.014

[9] C. Peralta, L. Fernández and A. Masi, "A Novel Application of Immobilization on Membranes for the Separation and Spectrofluorimetric Quantification of Amiloride and Furosemide in Pharmaceutical Samples," Analytica Chimica Acta, Vol. 661, No. 1, 2010, pp. 85-90. doi:10.1016/j.aca.2009.12.015

[10] W. Kaim and B. Schwederski, "Bioinorganic Chemistry: Inorganic Elements in the Chemistry of Life," Wiley, New York, 1994.

[11] L. R. Goldfrank, "Goldfrank's Toxicologic Emergencies," 8th Edition, McGraw Hill, New York, 2006.

[12] I. Gaubeur, L. H. S. Avila-Terra, J. C. Masini and M. E. V. Suárez-Iha, "Analytical Sciences," The International Journal of the Japan Society for Analytical Chemistry, Vol. 23, 2007, pp. 227-1231.

[13] C. Terrés-Martos, M. Navarro-Alarcón, F. Martin-Lagos, R. Giménez-Martínez, H. López-García De La Serrana and M. C. López-Martínez, Water Research, Vol. 36, No. 7, 2002, pp. 1912-1916. doi:10.1016/S0043-1354(01)00373-6

[14] O. I. Yurchenko, I. P. Kharenko and N. P. Titova, "Increasing the Sensitivity and Accuracy of Zinc Determination in Atomic Absorption Spectrometry," Journal of Applied Spectroscopy, Vol. 75, No. 2, 2008, pp. 283-287. doi:10.1007/s10812-008-9041-6

[15] M. Soylak and N. D. Erdogan, "Copper (II)-Rubeanic Acid Coprecipitation System for Separation-Preconcentration of Trace Metal Ions in Environmental Samples for Their Flame Atomic Absorption Spectrometric Determinations," Journal of Hazardous Materials, Vol. B137, No. 2, 2006, pp. 1035-1041. doi:10.1016/i.jhazmat.2006.03.031

[16] B. S. Shanbhag and Z. R. Turel, "Destructive and NondeStructive Analysis of Some Elements in Tissue and Environ-Mental Samples by Thermal Neutron Activation Analysis Technique," Journal of Radioanalytical and Nuclear Chemistry, Vol. 197, No. 2, 1995, pp. 417-425. doi:10.1007/BF02036015

[17] A. Montaser and W. Golightly, "Inductively Coupled Plasmas in Analytical Atomic Spectrometry," Wiley, New York, 1999.

[18] J. Wang, E. H. Hansen and B. Gammelgaard, "Flow Injection Online Dilution for Multi-Element Determination in Human Urine with Detection by Inductively Coupled Plasma Mass Spectrometry," Talanta, Vol. 55, No. 1, 2001, pp. 117-126. doi:10.1016/S0039-9140(01)00397-6

[19] A. Montaser and W. Golightly, "Inductively Coupled Plasmas Mass Spectrometry,” Wiley, New York, 1998.
[20] B. M. Wah Fong, T. S. Siu, J. S. Kit Lee and S. Tam, "Multi-Elements (Aluminium, Copper, Magnesium, Manganese, Selenium and Zinc) Determination in Serum by Dynamic Reaction Cell-Inductively Coupled PlasmaMass Spectrometry," Clinical Chemistry and Laboratory Medicine, Vol. 47, 2009, pp. 75-78. doi:10.1515/CCLM.2009.006

[21] M. Luconi, R. Olsina, L. Fernández and M. Silva, "Determination of Lead in Human Saliva by Combined Cloud Point Extraction-Capillary Zone Electrophoresis with Indirect uv Detection," Journal of Hazardous Materials, Vol. 128, No. 2-3, 2005, pp. 240-246. doi:10.1016/j.jhazmat.2005.08.007

[22] C. Wang, M. Luconi, A. Masi and L. Fernández, "Determination of Terazosin by Cloud Point ExtractionFluorimetric Combined Methodology," Talanta, Vol. 72, No. 5, 2007, pp. 1779-1785. doi:10.1016/j.talanta.2007.02.010

[23] C. Wang, A. Masi and L. Fernández, "On-Line Micellar Enhanced Spectrofluorimetric Determination of Rhodamine Dye in Cosmetics," Talanta, Vol. 75, 2008, pp. 135- 140.

[24] R. Silva, C. Wang, L. Fernández and A. Masi, "Flow injection Spectrofluorimetric Determination of Carvedilol Mediated by Micelles," Talanta, Vol. 76, No. 1, 2008, pp. 166-171. doi:10.1016/j.talanta.2008.02.029

[25] M. C. Talio, M. O. Luconi, A. N. Masi and L. P. Fernández, "Determination of Cadmium at Ultra-Trace Levels by CPE-Molecular Fluorescence Combined Methodology," Journal of Hazardous Materials, Vol. 170, No. 1, 2009, pp. 272-277. doi:10.1016/j.jhazmat.2009.04.101

[26] L. Gzara and M. Dhahbi, "Removal of Chromate Anions by Micellar Enhanced Ultrafiltration Using Cationic Surfacetants," Desalination, Vol. 137, No. 1-3, 2001, pp. 13-19. doi:10.1016/S0011-9164(01)00225-9

[27] J. Huanga, G. Zenga, C. Zhoua, X. Li, L. Shia and S. He, "Adsorption of Surfactant Micelles and $\mathrm{Cd} 2+/ \mathrm{Zn} 2+$ in Micellar-Enhanced Ultrafiltration," Journal of Hazardous Materials, Vol. 183, No. 1-3, 2010, pp. 287-293. doi:10.1016/j.jhazmat.2010.07.022

[28] J. Wan, Z. Li, Xi. Lu and S. Yuan, "Remediation of a Hexachlorobenzene-Contaminated Soil by Surfactant-Enhanced Electrokinetics Coupled with Microscale $\mathrm{Pd} / \mathrm{Fe}$ PRB," Journal of Hazardous Materials, Vol. 184, No. 1-3, 2010, pp. 184-190. doi:10.1016/j.jhazmat.2010.08.022

[29] M. C. Talio, M. O. Luconi, A. N. Masi and L. P. Fernández, "Solid Surface Spectroscopic Methodology for Ultra-Trace Urinary Nickel Monitoring in Smokers and Non-Smokers' Subjects," Journal of Pharmaceutical and Biomedical Analysis, Vol. 52, No. 5, 2010, pp. 694700. doi:10.1016/j.jpba.2010.02.013

[30] M. C. Talio, M. O. Luconi, A. N. Masi and L. P. Fernández, "Cadmium Monitoring in Saliva and Urine as Indicator of Smoking Addiction," Science of The Total Environment, Vol. 408, No. 16, 2010, pp. 3125-3132. doi:10.1016/j.scitotenv.2010.03.052 